\title{
PERBANYAKAN TANAMAN NILAM ACEH (Pogostemon cablin Benth.) DENGAN KOMBINASI IAA DAN KINETIN SECARA IN VITRO
}

\section{In Vitro Propagation of Aceh Patchouli (Pogostemon cablin Benth.) by Combining IAA and Kinetin}

\author{
Marai Rahmawati ${ }^{1 *}$, Cut Nurul Safira ${ }^{1}$, Mardhiah Hayati ${ }^{1}$, \\ ${ }^{1}$ Jurusan Agroteknologi, Fakultas Pertanian, Universitas Syiah Kuala \\ Jl. Tgk. Hasan Krueng Kale No.3, Kopelma Darussalam, Kec. Syiah Kuala, Kota Banda Aceh, 23111 \\ *)Corresponding author: marai_rahmawati@unsyiah.ac.id
}

\begin{abstract}
Abstrak. Penelitian ini bertujuan untuk mengetahui pengaruh pemberian beberapa konsentrasi IAA dan Kinetin terhadap pertumbuhan tanaman nilam Aceh secara in vitro. Penelitian ini dilaksanakan di Laboratorium Kultur Jaringan Tanaman, Fakultas Pertanian, Universitas Syiah Kuala, pada bulan Juni sampai dengan November 2020. Penelitian ini dilakukan dengan menggunakan faktor konsentrasi IAA yang terdiri dari empat taraf, yaitu $0 \mathrm{mg} \mathrm{L}^{-1} ; 0,25 \mathrm{mg} \mathrm{L}^{-1}$; $0,5 \mathrm{mg} \mathrm{L}^{-1}$; dan $0,75 \mathrm{mg} \mathrm{L}^{-1}$ serta faktor konsentrasi Kinetin yang terdiri dari empat taraf, yaitu 0 $\mathrm{mg} \mathrm{L}^{-1} ; 1 \mathrm{mg} \mathrm{L}^{-1} ; 2 \mathrm{mg} \mathrm{L}^{-1}$; dan $3 \mathrm{mg} \mathrm{L}^{-1}$. Hasil penelitian menunjukkan persentase eksplan hidup tertinggi $60 \%$ dan persentase kontaminasi terendah $20 \%$ adalah pada perlakuan $0 \mathrm{mg} \mathrm{L}^{-1}$ IAA +1 $\mathrm{mg} \mathrm{L}^{-1}$ kinetin. Persentase hidup tertinggi $60 \%$ dan persentase browning terendah $0 \%$ adalah pada perlakuan $0 \mathrm{mg} \mathrm{L}^{-1} \mathrm{IAA}+2 \mathrm{mg} \mathrm{L}^{-1}$ kinetin. Eksplan tanaman nilam tertinggi dan jumlah tunas terbanyak pada umur $10 \mathrm{MSI}$, serta jumlah daun terbanyak pada umur 5 MSI dan $10 \mathrm{MSI}$ adalah pada perlakuan $0,75 \mathrm{mg} \mathrm{L}^{-1} \mathrm{IAA}+0 \mathrm{mg} \mathrm{L}^{-1}$ Kinetin.
\end{abstract}

\section{Kata kunci ; Nilam, IAA, Kinetin, in vitro}

Abstract. This study aims to determine the effect of giving several concentrations of IAA and Kinetin on the growth of Aceh patchouli in vitro. This research was conducted at the Laboratory of Plant Tissue Culture, Faculty of Agriculture, Universitas Syiah Kuala, from June to November 2020. This research was conducted using four different concentrations of IAA: $0 \mathrm{mg} \mathrm{L}^{-1} ; 0.25 \mathrm{mg}$ $\mathrm{L}^{-1} ; 0.5 \mathrm{mg} \mathrm{L}^{-1}$; and $0.75 \mathrm{mg} \mathrm{L}^{-1}$, and four different concentrations of Kinetin: $0 \mathrm{mg} \mathrm{L}^{-1} ; 1 \mathrm{mg} \mathrm{L}^{-1}$; $2 \mathrm{mg} \mathrm{L}^{-1}$; and $3 \mathrm{mg} \mathrm{L}^{-1}$. The results showed the highest percentage of live explants was $60 \%$ and the lowest contamination percentage was $20 \%$ in the combination of $0 \mathrm{mg} \mathrm{L}^{-1} \mathrm{IAA}+1 \mathrm{mg} \mathrm{L}^{-1}$ Kinetin. The highest percentage of life was $60 \%$ and the lowest percentage of browning was $0 \%$ in the combination of $0 \mathrm{mg} \mathrm{L}^{-1} \mathrm{IAA}+2 \mathrm{mg} \mathrm{L}^{-1}$ Kinetin. The highest height of patchouli explants and the highest number of shoots were found at 10 weeks after inoculation. The application of $0.75 \mathrm{mg}$ $\mathrm{L}^{-1}$ IAA $+0 \mathrm{mg} \mathrm{L}^{-1}$ Kinetin possessed the highest number of leaves at 5 and 10 weeks after inoculation.

Keywords; Patchouli, IAA, Kinetin, in vitro

\section{PENDAHULUAN}

Nilam (Pogostemon cablin Benth.) merupakan salah satu komoditi penghasil minyak atsiri yang dibutuhkan pada berbagai sektor industri. Menurut Amalia \& Hadipoentyanti (2018), hampir 90\% pemenuhan kebutuhan minyak nilam dunia berasal dari Indonesia. Indrawanto \& Syakir (2008) menyatakan minyak nilam memiliki prospek sebagai komoditas ekspor unggulan karena secara kontinyu dibutuhkan sebagai salah satu bahan baku utama dalam pembuatan produk seperti kosmetik, parfum, hingga obatobatan. Menurut Sahwalita \& Herdiana (2015), minyak atsiri yang berasal dari tanaman nilam memiliki daya fiksasi yang tinggi terhadap campuran bahan pewangi lain, serta dapat mengikat dan mencegah penguapan aroma sehingga dapat bertahan lebih lama. Berdasarkan hal tersebut, nilam telah menjadi tanaman yang sangat potensial untuk dikembangkan, baik dari segi peningkatan kualitas mutu maupun upaya perbanyakannya. 
Berdasarkan data Direktorat Jenderal Perkebunan (2019), sekitar 33 persen dari ratarata produksi nilam yang dihasilkan di Indonesia berasal dari Aceh. Aceh memiliki empat kabupaten yang menjadi sentra produksi tanaman dan minyak atsiri nilam terbesar di Indonesia, yaitu kabupaten Aceh Selatan, Aceh Barat, Gayo Lues, dan Aceh Jaya. Menurut Balai Penelitian Tanaman Rempah dan Obat (2016), nilam Aceh mengandung sekitar 2,5$5 \%$ kadar minyak atsiri sehingga lebih diminati oleh pasar. Jenis nilam lainnya seperti nilam jawa (Pogostemon heyneanus) dan nilam sabun (Pogostemon hortensis) memiliki kandungan minyak atsiri yang lebih rendah yaitu berkisar antara 0,5-1,5\%. Hal tersebut menyebabkan tanaman nilam Aceh menjadi yang paling diminati untuk dikembangkan serta hasil penyulingan minyak atsiri nilam Aceh terbukti telah menembus pasar internasional.

Karakteristik tanaman nilam Aceh yang tidak memiliki biji sebagai organ perkembangbiakan generatif menyebabkan perbanyakan tanaman nilam Aceh biasa dilakukan secara vegetatif menggunakan bagian tunas akar. Menurut Hatta et al., (2008), nilam Aceh yang merupakan tanaman potensial untuk dikembangan ini tidak memiliki bunga, sehingga keragaman genetik tanaman juga sangat rendah. Kultur jaringan sebagai dasar dari aplikasi bioteknologi juga dapat ditindak lanjut sebagai upaya untuk meningkatkan keragaman genetik tanaman nilam Aceh.

Perbanyakan tanaman nilam secara kultur jaringan merupakan upaya untuk menghasilkan bibit dalam kuantitas yang banyak dan berkualitas. Menurut Anitasari et al., (2018), kultur jaringan adalah cara menumbuhkan dan memperbanyak sel, jaringan, dan organ tanaman dalam kondisi aseptis secara in vitro, guna menghasilkan bibit tanaman baru dengan sifat yang identik seperti tanaman induknya, bebas dari penyakit, dan dengan waktu yang relatif lebih singkat. Pengembangan teknik kultur jaringan pada tanaman nilam Aceh ditujukan antara lain untuk menyediakan benih klonal dalam jumlah besar yang diperlukan untuk memenuhi kebutuhan bibit tanaman nilam yang terus meningkat.
Penggunaan Zat Pengatur Tumbuh (ZPT) pada kultur jaringan tanaman mempengaruhi arah pertumbuhan jaringan tanaman. Menurut Suminar et al., (2015), keberhasilan perbanyakan tanaman secara in vitro merujuk pada syarat media tumbuh tanamanyang harus mengandung semua zat yang diperlukan oleh eksplan dalam mendukung proses pertumbuhan dan perkembangannya. Menurut Fried \& Hademenos (2006), auksin memainkan peranan penting dalam beragam perilaku dan pola pertumbuhan tanaman, terutama pada perkembangan sistem akar dan tunas. Lebih lanjut Firmansyah et al. (2007) menyatakan bahwa auksin merangsang pemanjangan sel pada konsentrasi tertentu. Jika konsentrasi auksin terlalu tinggi, maka pemanjangan akar dan batang menjadi terhambat. Hartmann et al., (2001), IAA yang merupakan salah satu jenis auksin memiliki sifat mudah diserap oleh tanaman karena memiliki struktur kimia yang tidak berbeda dengan auksin alami pada tanaman. Sitokinin berperan dalam merangsang pembelahan sel pada tanaman. Sitokinin juga dibutuhkan untuk pembentukan organel-organel semacam kloroplas. Dalam prosesnya, sitokinin berinteraksi dengan auksin untuk menentukan diferensiasi jaringan meristematik (Fried \& Hademenos, 2006).

Meskipun masing-masing ZPT memiliki peranan dalam mempengaruhi pertumbuhan tanaman, namun tak jarang kedua jenis ZPT dibutuhkan secara bersamaan pada perbandingan atau ratio tertentu. Adanya salah satu ZPT tertentu dapat meningkatkan maupun menurunkan aktivitas ZPT lainnya (Lestari, 2011). Berdasarkan penelitian Wardani (2016), terdapat interaksi atau pengaruh pada hasil kultur jaringan tanaman dengan menggunakan kombinasi ZPT jenis auksin dan sitokinin. Penggunaan ZPT sitokinin dan auksin dalam satu media tanam kultur jaringan dapat memacu poliferasi tunas yang disebabkan karena adanya pengaruh sinergisme antara kedua zat tersebut.

Penelitian mengenai kombinasi auksin dan sitokinin pada tanaman nilam yaitu berupa kombinasi IAA dan BAP telah dilakukan oleh Hatta et al., (2008) dan mendapatkan hasil bahwa kehadiran IAA menyebabkan BAP memberikan pengaruh negatif terhadap 
pembentukan daun tanaman nilam. Trimulyono et al., (2002) dalam penelitiannya mendapatkan hasil yaitu pemberian auksin jenis 2,4-D dan sitokinin jenis Kinetin dengan konsentrasi $0,5 \mathrm{mg} \mathrm{L}^{-1}$ mampu menginduksi terbentuknya kalus pada tanaman nilam. Menurutnya, pada konsentrasi tersebut kedua ZPT mampu merangsang sel melakukan proses dediferensiasi membentuk kalus.

Darunde \& Pandey (2019), melaporkan respon pembentukan akar terbaik pada kultur jaringan tanaman nilam yaitu pada pemberian konsentrasi $0,5 \mathrm{mg} \mathrm{L}^{-1} \mathrm{IAA}+1 \mathrm{mg}$ $\mathrm{L}^{-1}$ IBA. Hal ini menunjukkan bahwa konsentrasi dan jenis auksin yang sesuai dapat membantu meningkatkan pertumbuhan tanaman nilam khususnya pada pembentukan akar tanaman. Sharma \& Sarma (2016) dalam penelitiannya membuktikan bahwa interaksi auksin dan sitokinin yaitu berupa pemberian IBA $0,1 \mathrm{mg} \mathrm{L}^{-1}$ dan Kinetin $2,5 \mathrm{mg} \mathrm{L}^{-1}$ memberikan tingkat multiplikasi maksimum dalam proporsi generasi tunas, daun, akar, dan kalus tanaman nilam.

Berdasarkan latar belakang tersebut, penelitian ini dilakukan dengan menggunakan kombinasi beberapa konsentrasi ZPT IAA dan Kinetin untuk melihat pengaruhnya pada perbanyakan tanaman nilam Aceh secara in vitro.

\section{METODE PENELITIAN}

Penelitian ini dilaksanakan di Laboratorium Kultur Jaringan Tanaman, Jurusan Agroteknologi, Fakultas Pertanian, Universitas Syiah Kuala, Darussalam, Banda Aceh. Pelaksanaan penelitian dimulai pada Juni sampai dengan November 2020.

Alat-alat yang digunakan dalam pelaksanaan penelitian ini antara lain yaitu autoclave, hot plate dan magnetic stirrer, spatula, Laminar Air Flow Cabinet (LAFC), sedangkan bahan-bahan yang digunakan dalam pelaksanaan penelitian ini antara lain yaitu tunas pucuk tanaman nilam Aceh, larutan stok A, B, C, D, E, F, Vitamin, Mio-inotisol, agaragar, akuades steril, Indole Acetic Acid (IAA), Kinetin, alkohol 70\%, betadine, bayclin, spiritus, detergen cair.

Penelitian ini terdiri atas dua faktor yaitu konsentrasi IAA yang terdiri atas empat taraf, yaitu $0 ; 0,25 ; 0,5 ;$ dan $0,75 \mathrm{mg} \mathrm{L}^{-1}$ dan konsentrasi Kinetin yang terdiri atas empat taraf, yaitu $0 ; 1 ; 2 ; 3 \mathrm{mg} \mathrm{L}^{-1}$. Terdapat 16 kombinasi perlakuan dengan 5 kali ulangan, sehingga diperoleh 80 satuan percobaan.

\section{Pelaksanaan Penelitian}

Sumber eksplan berasal dari batang tanaman nilam Aceh varietas Tapak Tuan yang diperoleh dari Aceh Jaya. Batang tanaman nilam distek dan ditanam dalam polybag dengan media tanah dan pupuk kandang. Stek tanaman nilam diberi naungan paranet, dan disiram setiap pagi dan sore hari. Pucuk stek tanaman nilam kemudian digunakan sebagai eksplan setelah berumur 3 bulan.

Persiapan alat dan media kultur in vitro meliputi sterilisasi aquades, pembuatan larutan stok, pembuatan media tanam Murashige and Skoog (MS), sterilisasi alat, pembuatan larutan sterilisasi, sterilisasi ruang tanam. Sterilisasi eksplan dilakukan pada bagian tunas pucuk tanaman nilam. Eksplan dicuci dengan air mengalir, kemudian disikat secara perlahan satu persatu menggunakan kuas cat. Eksplan kemudian dimasukkan dalam larutan detergen cair $5 \mathrm{ml} \mathrm{L}^{-1}$ air sambil diaduk selama 5 menit. Selanjutnya eksplan dibilas sebanyak 3 kali dan dimasukkan kedalam LAFC.

Sterilisasi selanjutnya dilakukan didalam LAFC dan dekat dengan bunsen spiritus yang telah dinyalakan. Eksplan direndam dalam alkohol 70\% sambil diaduk selama 30 detik, kemudian dibilas sebanyak 3 kali menggunakan aquadest steril. Selanjutnya eksplan direndam dalam larutan clorox 30\% sambil diaduk selama 5 menit, dan dibilas menggunakan aquadest steril sebanyak 3 kali. Terakhir, eksplan dibilas dengan aquadest steril yang telah diberikan 5 tetes betadine.

Selanjutnya eksplan dipotong hingga berukuran kurang lebih $1 \mathrm{~cm}$ dan ditanam dalam setiap botol kultur berisi satu eksplan tanaman nilam. Pemeliharaan eksplan dilakukan sampai tanaman berumur 10 MSI.

\section{Parameter Pengamatan}

Pengamatan eksplan tanaman nilam Aceh dilakukan setiap minggu, yang dimulai sejak umur 1 sampai 10 MSI. Parameter yang diamati meliputi persentase eksplan hidup, persentase kontaminasi, persentase browning, tinggi tanaman, jumlah tunas dan jumlah daun. Hasil pengamatan pada penelitian ini tidak dapat diolah menggunakan rancangan statistik 
dikarenakan data tidak menyebar normal akibat rendahnya persentase hidup.

\section{HASIL DAN PEMBAHASAN}

\section{Persentase Hidup Eksplan, Kontaminasi dan Browning}

Eksplan tanaman nilam yang tumbuh berdasarkan kombinasi perlakuan ZPT memiliki persentase hidup yang beragam. Berdasarkan data pada Tabel 1, eksplan tanaman nilam hasil inisiasi yang berhasil hidup dan tumbuh hanya mencapai persentase tertinggi $60 \%$. Perlakuan $0 \mathrm{mg} \mathrm{L}^{-1} \mathrm{IAA}+1 \mathrm{mg}$ $\mathrm{L}^{-1}$ Kinetin dan $0 \mathrm{mg} \mathrm{L}^{-1}$ IAA $+2 \mathrm{mg} \mathrm{L}^{-1}$ Kinetin merupakan kombinasi perlakuan yang konsisten mencapai persentase hidup 60\% hingga waktu pengamatan terakhir, yaitu pada umur 10 MSI. Eksplan tanaman nilam dengan kombinasi perlakuan $0 \mathrm{mg} \mathrm{L}{ }^{-1} \mathrm{IAA}+3 \mathrm{mg} \mathrm{L}^{-1}$ Kinetin sampai umur 4 MSI juga memiliki persentase hidup $60 \%$, namun menurun menjadi $40 \%$ pada minggu selanjutnya hingga umur 10 MSI, hal ini disebabkan karena terjadinya kontaminasi pada sebagian eksplan.
Kombinasi perlakuan $0 \mathrm{mg} \mathrm{L}^{-1}$ IAA +0 $\mathrm{mg} \mathrm{L}^{-1}$ Kinetin dan $0,5 \mathrm{mg} \mathrm{L}^{-1} \mathrm{IAA}+1 \mathrm{mg} \mathrm{L}^{-1}$ Kinetin memiliki persentase hidup $0 \%$ yang berarti tidak ada eksplan nilam yang berhasil tumbuh pada kedua perlakuan tersebut. Banyaknya jumlah eksplan tanaman nilam yang tidak tumbuh diduga disebabkan oleh kondisi sumber tanaman yang digunakan serta proses pelaksanaan yang kurang hati-hati. Kondisi sumber bahan tanam yang digunakan antara satu tanaman dengan tanaman yang lain dapat sangat berbeda.

Berdasarkan penelitian yang telah dilakukan, persentase hidup eksplan tanaman nilam tidak dapat selalu dipertahankan. Kegagalan hidup eksplan tidak harus terjadi pada masa awal penanaman. Eksplan dapat mengalami kontaminasi dan browning bahkan pada umur 5, 6, dan 7 MSI. Perbedaan yang sangat jelas pada persentase hidup eksplan tanaman nilam antar kombinasi perlakuan penelitian ini tidak menunjukkan pengaruh atau keterkaitan dengan ZPT yang digunakan.

Tabel 1. Persentase Eksplan Hidup, Persentase Kontaminasi, dan Persentase Browning Eksplan tanaman Nilam pada Minggu ke-1, 5 dan 10

\begin{tabular}{cccccccccc}
\hline Konsentrasi & \multicolumn{3}{c}{ Persentase Eksplan } & \multicolumn{3}{c}{ Persentase Kontaminasi } & \multicolumn{3}{c}{ Persentase Bowning } \\
\cline { 2 - 10 } IAA + Kinetin & 1 & 5 & 10 & 1 & 5 & 10 & 1 & 5 & 10 \\
\hline $0,0+0$ & 0 & 0 & 0 & 60 & 60 & 60 & 40 & 40 & 40 \\
$0,0+1$ & 60 & 60 & 60 & 20 & 20 & 20 & 20 & 20 & 20 \\
$0,0+2$ & 60 & 60 & 60 & 40 & 40 & 40 & 0 & 0 & 0 \\
$0,0+3$ & 60 & 40 & 40 & 20 & 40 & 40 & 20 & 20 & 20 \\
$0,25+0$ & 40 & 40 & 20 & 40 & 40 & 60 & 20 & 20 & 20 \\
$0,25+1$ & 40 & 40 & 40 & 20 & 20 & 20 & 40 & 40 & 40 \\
$0,25+2$ & 40 & 40 & 40 & 20 & 20 & 20 & 40 & 40 & 40 \\
$0,25+3$ & 20 & 20 & 20 & 60 & 60 & 60 & 20 & 20 & 20 \\
$0,50+0$ & 20 & 20 & 20 & 40 & 40 & 40 & 40 & 40 & 40 \\
$0,50+1$ & 0 & 0 & 0 & 80 & 80 & 80 & 20 & 20 & 20 \\
$0,50+2$ & 20 & 20 & 0 & 60 & 60 & 80 & 20 & 20 & 20 \\
$0,50+3$ & 20 & 20 & 20 & 20 & 20 & 20 & 60 & 60 & 60 \\
$0,75+0$ & 40 & 40 & 40 & 40 & 40 & 40 & 20 & 20 & 20 \\
$0,75+1$ & 20 & 20 & 20 & 80 & 80 & 80 & 0 & 0 & 0 \\
$0,75+2$ & 20 & 20 & 0 & 80 & 80 & 80 & 0 & 0 & 20 \\
$0,75+3$ & 20 & 20 & 20 & 60 & 60 & 60 & 20 & 20 & 20 \\
\hline
\end{tabular}

Terjadinya kontaminasi dapat menyebabkan kegagalan pada teknik kultur jaringan tanaman. Menurut Fitriani et al. (2019), kontaminasi yang disebabkan oleh mikroorganisme yang hidup didalam sel tanaman atau ruang antar sel sangat sulit diatasi dengan sterilisasi permukaan. Kontaminan yang menginfeksi permukaan 
eksplan akan memberikan respon dalam kurun waktu 48 jam, namun kontaminan yang bersifat internal akan terlihat lebih lambat yaitu sebulan atau lebih setelah inisiasi.

Tabel 1 menunjukkan bahwa nilai kontaminasi yang terjadi pada eksplan tanaman nilam sangat tinggi hingga mencapai persentase tertinggi $80 \%$, yaitu yang terjadi pada eksplan tanaman nilam dengan kombinasi perlakuan $0,5 \mathrm{mg} \mathrm{L}^{-1} \mathrm{IAA}+1 \mathrm{mg} \mathrm{L}^{-1}$ Kinetin, $0,75 \mathrm{mg} \mathrm{L}^{-1} \mathrm{IAA}+1 \mathrm{mg} \mathrm{L}^{-1}$ Kinetin, serta 0,75 mg $\mathrm{L}^{-1}$ IAA $+2 \mathrm{mg} \mathrm{L}^{-1}$ Kinetin. Beberapa kombinasi perlakuan mengalami penambahan persentase kontaminasi setelah melewati satu bulan masa inisiasi. Kombinasi perlakuan $0 \mathrm{mg}$ $\mathrm{L}^{-1} \mathrm{IAA}+3 \mathrm{mg} \mathrm{L}^{-1}$ Kinetin mengalami penambahan kontaminasi pada 5 MSI, sementara itu kombinasi perlakuan $0,25 \mathrm{mg} \mathrm{L}^{-1}$ IAA $+0 \mathrm{mg} \mathrm{L}^{-1}$ Kinetin dan $0,5 \mathrm{mg} \mathrm{L}^{-1} \mathrm{IAA}+$

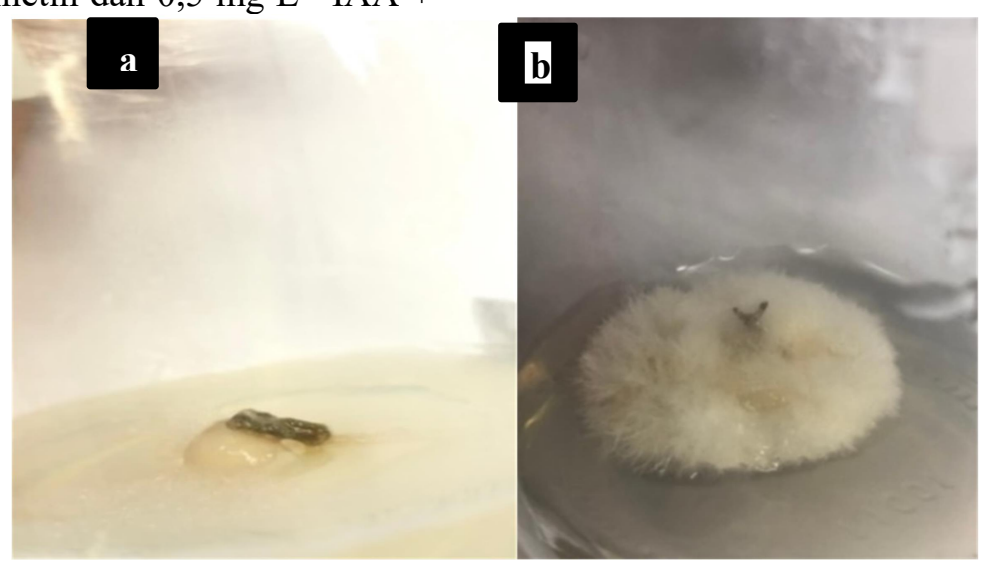

Gambar 1. Perbedaan eksplan tanaman nilam yang terkontaminasi oleh bakteri (a) dan jamur (b)

Eksplan tanaman nilam yang tidak berhasil hidup selain karena disebabkan oleh kontaminasi, juga disebabkan oleh browning eksplan. Browning merupakan keadaan dimana ekplan tanaman mengalami perubahan warna menjadi coklat setelah proses inisiasi, perubahan ini dapat menghambat pertumbuhan jaringan dan menyebabkan kematian tanaman. Menurut Megasari et al., (2020), terjadinya browning disebabkab oleh adanya fenol yang dihasilkan eksplan tanaman akibat dari proses pemotongan batang eksplan, hal ini menyebabkan jaringan tanaman teroksidasi. Santoso \& Nursandi (2004) menyatakan faktor teknis pada proses penanaman seperti penggunaan scapel dan pinset yang masih panas serta lamanya proses pengeringan
$2 \mathrm{mg} \mathrm{L} \mathrm{L}^{-1}$ Kinetin mengalami penambahan kontaminasi pada $10 \mathrm{MSI}$.

Mikroorganisme dapat masuk pada saat proses penanaman maupun pemeliharaan. Udara sebagai pembawa bahan partikulat, debu, dan tetesan air dapat sebagai tempat tumbuh bakteri. Menurut Wojtania dan Pulawska (2005), kontaminasi yang disebabkan oleh bakteri dapat menyebabkan kondisi eksplan berair serta berlendir. Patogen jamur yang menginfeksi eksplan kultur jaringan tanaman nilam ditandai dengan ciri berwarna putih dan membentuk benangbenang halus serta menyebar hingga menutupi permukaan eksplan dan media tanam (Gambar 1). eksplan yang telah disterilisasi juga dapat menjadi penyebab terjadinya browning.

Persentase browning tertinggi yaitu $60 \%$ hanya terjadi pada eksplan tanaman nilam dengan kombinasi perlakuan $0,5 \mathrm{mg} \mathrm{L}^{-1} \mathrm{IAA}+$ $3 \mathrm{mg} \mathrm{L}^{-1}$ Kinetin. Pada Tabel 1 dapat dilihat bahwa terdapat banyak kombinasi perlakuan yang memiliki persentase browning $0 \%$, yang berarti tidak ada ekplan pada kombinasi perlakuan tersebut yang mengalami browning. Pada sebagian besar eksplan, browning terjadi pada umur 1 MSI tanpa adanya penambahan pada minggu selanjutnya, kecuali yang terjadi pada kombinasi perlakuan $0,75 \mathrm{mg} \mathrm{L}^{-1}$ IAA + $2 \mathrm{mg} \mathrm{L}^{-1}$ Kinetin yang mengalami penambahan eksplan browning pada umur 6 MSI, hal ini menunjukkan bahwa browning tidak selalu 
terjadi pada masa awal inisiasi, namun dapat terjadi selama masa inisiasi.

\section{Pertumbuhan Ekplan Tanaman Nilam}

Eksplan nilam yang berhasil tumbuh dengan baik yaitu pada enam kombinasi

Tabel 2. Tinggi Tanaman, Jumlah Tunas dan Jumlah Daun Eksplan Tanaman Nilam pada Minggu ke-1, 5 dan 10 konsentrasi IAA dan Kinetin. Eksplan tersebut mengalami penambahan tinggi tanaman, pembentukan tunas dan daun sebagaimana ditampilkan pada Tabel 2.

\begin{tabular}{ccccccccccc}
\hline $\begin{array}{c}\text { Perlakuan } \\
\text { Konsentrasi } \\
\text { IAA + Kinetin } \\
\left(\mathrm{ml} \mathrm{L}^{-1}\right)\end{array}$ & \multicolumn{2}{c}{ Tinggi Tanaman $(\mathrm{cm})$} & \multicolumn{3}{c}{ Jumlah Tunas (tunas) } & \multicolumn{3}{c}{ Jumlah Daun (helai) } \\
\cline { 2 - 11 } & 1 & 5 & 10 & 1 & 5 & 10 & 1 & 5 & 10 \\
\hline $0,00+1$ & 1,1 & 2,5 & 4,5 & 1 & 2 & 13 & 2 & 13 & 34 \\
$0,00+2$ & 1,8 & 3,2 & 4,8 & 3 & 6 & 6 & 2 & 18 & 32 \\
$0,00+3$ & 2,2 & 3,8 & 4,6 & 1 & 3 & 6 & 2 & 28 & 43 \\
$0,25+1$ & 2,5 & 4,2 & 5,8 & 2 & 4 & 4 & 2 & 29 & 42 \\
$0,25+2$ & 1,4 & 2,7 & 4,5 & 1 & 3 & 3 & 2 & 11 & 25 \\
$0,75+0$ & 1,8 & 3 & 6,7 & 0 & 4 & 23 & 2 & 38 & 66 \\
\hline
\end{tabular}

Eksplan tanaman nilam yang tumbuh dengan baik $50 \%$ berasal dari kombinasi tanpa IAA. Menurut Lestari (2011), kombinasi penggunaan auksin dan sitokinin pada media akan memacu proliferasi tunas karena adanya pengaruh sinergisme antara kedua ZPT tersebut, meskipun demikian faktor 
Sedangkan pada jumlah tunas terbanyak pada 1 dan 5 MSI terdapat pada eksplan dengan kombinasi $0 \mathrm{mg} \mathrm{L}^{-1} \mathrm{IAA}+2 \mathrm{mg} \mathrm{L}^{-1}$ Kinetin, namun pada 10 MSI jumlah tunas pada eksplan tersebut tidak bertambah
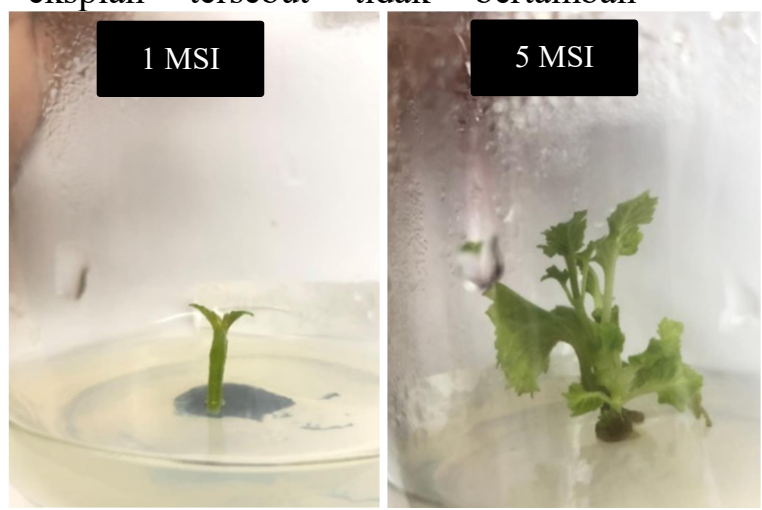

(Gambar 3). Kombinasi $0,75 \mathrm{mg} \mathrm{L}^{-1} \mathrm{IAA}+0$ $\mathrm{mg} \mathrm{L}^{-1}$ Kinetin justru menghasilkan jumlah tunas yang terbanyak pada 10 MSI yaitu 23 tunas (Gambar 4).

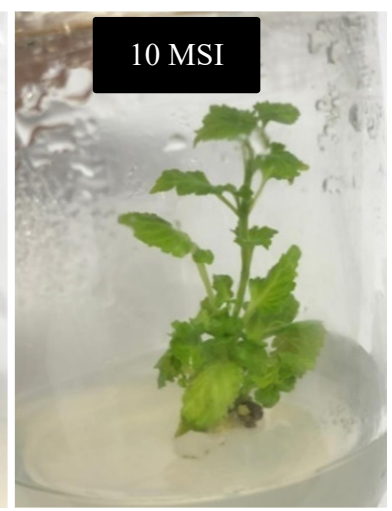

Gambar 3. Eksplan tanaman nilam pada media kombinasi $0 \mathrm{mg} \mathrm{L}^{-1} \mathrm{IAA}+2 \mathrm{mg} \mathrm{L}^{-1}$ Kinetin pada umur 1, 5, dan $10 \mathrm{MSI}$
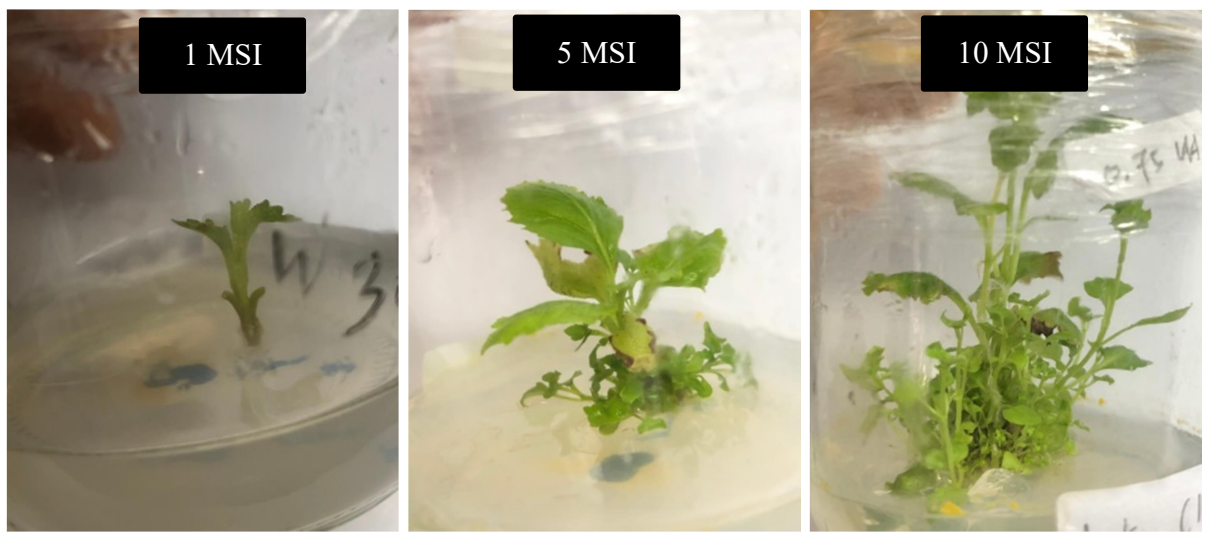

Gambar 4. Eksplan tanaman nilam pada media kombinasi $0,75 \mathrm{mg} \mathrm{L}^{-1} \mathrm{IAA}+0 \mathrm{mg} \mathrm{\textrm {L } ^ { - 1 }}$ Kinetin pada umur 1, 5, dan $10 \mathrm{MSI}$

Menurut para ahli, tunas merupakan bagian tumbuhan yang tumbuh dari kecambah atau kuncup yang berada diatas permukaan media. Tunas dapat terdiri dari batang dan ditambah dengan daun muda. Menurut penelitian Swamy et al., (2010), Kinetin tidak berpengaruh signifikan terhadap regenerasi banyak tunas, namun berperan dalam peningkatan panjang dan kekuatan tunas. Wiraatmaja (2017) menyatakan meristem tunas apikal merupakan tempat utama sintesis auksin. Pada penelitian ini, kombinasi perlakuan yang menggunakan ZPT Kinetin menunjukkan pertumbuhan tunas yang cukup baik, namun oleh karena rendahnya persentase hidup, tidak dapat diperoleh hasil yang nyata antara pengaruh kombinasi IAA dan Kinetin terhadap pertumbuhan jumlah tunas eksplan tanaman nilam.

Setiap eksplan memiliki jumlah daun yang sama pada 1 MSI yaitu 2 helai daun, namun selanjutnya pada kombinasi $0,75 \mathrm{mg}$ 
IAA +0 mg Kinetin jumlah daun meningkat menjadi 38 helai pada 5 MSI dan 66 helai pada 10 MSI (Gambar 7). Daun sebagai organ vegetatif tanaman yang berbentuk pipih memegang peranan penting dalam proses metabolisme pertumbuhan dan perkembangan tanaman, diantaranya yaitu fotosisntesis dan respirasi. Jumlah daun terbanyak pada perlakuan tanpa Kinetin ini sesuai pernyataan Bushra et al., (2009) menyatakan bahwa eksplan yang berasal dari tunas pucuk telah memiliki kandungan sitokinin endogen yang cukup tinggi sehingga pada dasarnya mampu beregenerasi dengan baik untuk menghasilkan jumlah daun tanaman yang lebih banyak. Meskipun demikian, menurut Chakravarthi et al. (2010), pemberian ZPT sitokinin pada eksplan mata tunas dan tunas pucuk mampu menghasilkan jumlah daun yang lebih banyak.

\section{KESIMPULAN}

Persentase hidup eksplan tanaman nilam tertinggi adalah $60 \%$ pada perlakuan $0 \mathrm{mg} \mathrm{L}^{-1}$ IAA $+1 \mathrm{mg} \mathrm{L}^{-1}$ Kinetin dan $0 \mathrm{mg} \mathrm{L}^{-1} \mathrm{IAA}+2$ $\mathrm{mg} \mathrm{L}^{-1}$. Persentase eksplan hidup tertinggi $60 \%$, persentase kontaminasi terendah $20 \%$ dan persentase browning 20\% ditemukan pada perlakuan $0 \mathrm{mg} \mathrm{L}^{-1} \mathrm{IAA}+1 \mathrm{mg} \mathrm{L}^{-1}$ Kinetin. Persentase eksplan hidup tertinggi $60 \%$, persentase kontaminasi $40 \%$ dan persentase browning terendah $0 \%$ ditemukan pada

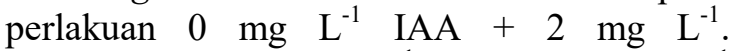
Konsentrasi $0,75 \mathrm{mg} \mathrm{L}^{-1}$ IAA $+0 \mathrm{mg} \mathrm{L}^{-1}$ Kinetin memberikan pengaruh terbaik terhadap tinggi eksplan, jumlah tunas serta jumlah daun pada 10 MSI.

\section{DAFTAR PUSTAKA}

Amalia \& E. Hadipoentyanti. 2018. Perbanyakan nilam (Pogostemon cablin Benth) menggunakan media dasar alternatif secara in vitro. Perspektif. 17 (2): 139-149.

Anitasari, S.D., D.N.R. Sari, I.A. Astarini dan M.R. Defiani. 2018. Dasar Teknik Kultur Jaringan Tanaman. Depublish. Yogyakarta.

Balai Penelitian Tanaman Rempah dan Obat. 2016. Kualitas Minyak Nilam. Balai
Penelitian Tanaman Rempah dan Obat. Bogor.

Bushra, Z., N. A. Abbasi, T. Ahmad \& I. A. Hafiz. 2009. Effect of explant sources and different concentrations of plant growth regulators on in vitro shoot proliferation and rooting. $\mathrm{J}$. Bot. 41 (5): 23-46.

Chakravarthi D. V. N., V. Indukuri, U. A. Goparaju \& V. Yechuri. 2010. Effect of genotype, explant and hormonal concentration on in vitro response of eggplant. Not Sci Biol. 2 (3): 77-85.

Darunde, D. \& S. Pandey. 2019. Standardization and optimization of initiation, shooting and rooting medium for patchouli micro propagation. International Journal of Trend in Scientific Research and Development (IJTSRD). 3 (3): 895-902.

Direktorat Jenderal Perkebunan. 2019. Statistik Perkebunan Nilam. Direktorat Jenderal Perkebunan. Jakarta.

Firmansyah, R., A. Mawardi \& M.U. Riandi. 2007. Mudah dan Aktif Belajar Biologi. Setia Purna Inves. Bandung.

Fitriani, Y., G. Wijana \& I.A.P Darmawati. 2019. Teknik sterilisasi dan efektivitas 2,4-D terhadap pembentukan kalus eksplan daun nilam (Pogostemon cablin Benth) in vitro. 8 (1): 41-52.

Fried, G.H \& G.J. Hademenos. 2006. Schaum's Outlines Biologi Edisi Kedua. Erlangga. Jakarta.

Hartmann, H.T., D.E. Kester, J.R. Davies \& Geneve. 2001. Plant Propagation Principles and Practices. Pearson. New York.

Hatta, M., M. Hayati \& U. Irayani. 2008. Pengaruh IAA dan BAP terhadap pertumbuhan tanaman nilam (Pogestemon cablin Benth) in vitro. Jurnal Floratek. 3 (1): 56-60.

Indrawanto, C \& M. Syakir. 2008. Analisa Usaha Tani Nilam. Balai Penelitian Tanaman Rempah dan Obat. Bogor. 
Lestari, E.G. 2011. Peranan zat pengatur tumbuh dalam perbanyakan tanaman melalui kultur jaringan. Jurnal AgroBiogen. 7 (1): 63-68.

Megasari, E., N. Hermita \& S. Susiyanti. 2020. Respon perkecambahan benih sintetik nilam (Pogostemon cablin Benth.) terhadap pemberian konsentrasi alginate dan NAA sintetik tanaman. Jurnal Agrista. 24 (1): $12-18$.

Sahwalita \& N. Herdiana. 2015. Budidaya Nilam dan Produksi Minyak Atsiri. Biodiversity and Climate Change. Palembang.

Santoso, U. \& F. Nursandi. 2004. Kultur Jaringan Tanaman. UMM Press. Malang.

Sharma, P \& J. Sarma. 2016. Pogostemon cablin (Blanco) Benth. (Lamiaceace): its enthnobotany and in vitro regeneration. PHCOG Journal. 7 (3): 152-156.

Suminar, E., I.R.D. Anjarsari, A. Nuraini \& Hapizhah. 2015. Pertumbuhan dan perkembangan tunas nilam var. Lhokseumawe dari jenis eksplan dengan sitokinin yang berbeda secara in vitro. Jurnal Kultivasi. 14 (2): 10-15.

Swamy, M.K., S. Balasubramanya \& M. Anuradha. 2010. In vitro multiplication of Pogostemon cablin Benth. through direct regeneration. African Journal of Biotechnology. 9 (14): 2069-2075.

Trimulyono, G., Solichatun \& S.D. Marliana. 2002. Pertumbuhan kalus dan kandungan minyak atsiri nilam (Pogostemon cablin (Blanco) Bth.) dengan perlakuan asam a-naftalen asetat (NAA) dan kinetin. Biofarmasi. 2 (1): 914.

Wardani, I. B. 2016. Pengaruh Kombinasi BAP-6 (6-Benzyl Amino Purine) dan NAA (Naphtalen Acetic Acid) terhadap Induksi Tunas Aksilar Cendana (Santalum album L.). Skripsi Universitas Negeri Maulana Malik Ibrahim. Malang.
Wiraatmaja, I.W. 2017. Zat Pengatur Tumbuh Auksin dan Cara Penggunaannya dalam Bidang Pertanian. Udayana University Press. Denpasar 